Open Access

\title{
Erratum to: Health information priorities for more effective implementation and monitoring of non-communicable disease programs in low- and middle-income countries: lessons from the Pacific
}

Hebe N. Gouda ${ }^{1 *}$, Nicola C. Richards ${ }^{2}$, Robert Beaglehole ${ }^{3}$, Ruth Bonita ${ }^{3}$ and Alan D. Lopez ${ }^{4}$

\section{Erratum}

After publication of the original article [1] it was noted that the author Nicola C. Richards' surname was spelled incorrectly. When published initially it was spelled 'Richardson'. This has now been corrected in the original article.

\footnotetext{
Author details

${ }^{1}$ School of Public Health, University of Queensland, Brisbane, QLD, Australia. ${ }^{2}$ World Health Organization, Western Pacific Regional Office, Suva, Fiji.

${ }^{3}$ School of Population Health, University of Auckland, Auckland, New Zealand. ${ }^{4}$ Melbourne School of Population and Global Health, the University of Melbourne, Melbourne, VIC, Australia.
}

Received: 5 October 2015 Accepted: 5 October 2015

Published online: 20 October 2015

\section{Reference}

1. Gouda HN, Richards NC, Beaglehole R, Bonita R, Lopez AD. Health

information priorities for more effective implementation and monitoring of non-communicable disease programs in low- and middle-income countries: lessons from the Pacific. BMC Medicine. 2015;13:233.

\footnotetext{
* Correspondence: h.gouda@uq.edu.au

'School of Public Health, University of Queensland, Brisbane, QLD, Australia
} Full list of author information is available at the end of the article

\section{Submit your next manuscript to BioMed Central and take full advantage of: \\ - Convenient online submission \\ - Thorough peer review \\ - No space constraints or color figure charges \\ - Immediate publication on acceptance \\ - Inclusion in PubMed, CAS, Scopus and Google Scholar \\ - Research which is freely available for redistribution \\ Submit your manuscript at

